\title{
The Development Stage of Bond Market in Mongolia among Asian Countries
}

\author{
Hiroyuki Taguchi ${ }^{1} \&$ Ganbold Bolormaa ${ }^{1}$ \\ ${ }^{1}$ Graduate School of Humanities and Social Sciences, Saitama University, Saitama, Japan \\ Correspondence: Hiroyuki Taguchi, Graduate School of Humanities and Social Sciences, Saitama University, Saitama, \\ Japan
}

Received: September 16, 2019

Accepted: October 2, $2019 \quad$ Available online: October 17, 2019

doi:10.11114/aef.v6i6.4568

URL: https://doi.org/10.11114/aef.v6i6.4568

\begin{abstract}
This paper aims to address the issue on bond market development by investigating the determinants of bond market development with a focus on Asian economies, and also by identifying the impediment factors to prevent its development in Mongolian economy. This paper contributes to the literature by enriching evidence of the determinants of bond market development with a focus on Asian economies with common characteristics such as their high dependence on banking sectors. In particular, while there have been few studies on an individual economy's bond market, the strategic contribution is to identify the Mongolia-specific factors to prevent her bond market development among Asian economies. The estimation result shows that the two manageable variables, namely, bureaucracy quality and level of interest rate, are major determinants for both public and private bond market development in Asian economies, and also that these determinants are main factors to prevent the Mongolian bond market from developing.
\end{abstract}

Keywords: bond market, Mongolia, Asian countries, bureaucracy quality, interest rate

\section{Introducation}

The economic system in Mongolia was transformed from a centrally planned economy to a market-based economy in early 1990s, and a great number of economic reforms have been undertaken since then. Under the market-based regime, Mongolian economy has recorded 6.3 percent real economic growth on the average for the period from 1993 to $2017 .{ }^{1}$ One of the driving forces of its high economic growth has been natural resource development in such mining sectors as gold, copper and coal. During the growth process, Mongolian economy has promoted its economic status from "low income" to "middle income" since 2007, according to the World Bank Classifications. ${ }^{2}$

In accordance with the economic development, Mongolian economy has also gone through its financial deepening in monetary and capital markets. Looking at the trend in the financial deepening in Mongolia by one of typical indicators, i.e., private credit by banks as percentage of $\mathrm{GDP}^{3}$ the ratio has increased from 4.9 percent in 1993 to 52.9 percent in 2016. Financial deepening and economic growth have a two-way relationship according to a vast body of literature. While financial markets deepen in response to growing demand for financial services as real activities expand, financial deepening also contributes to facilitating economic growth (e.g. MacKinnon, 1973; Shaw, 1973; Levine, 2005). In this context, Mongolian economy, as one of emerging market economies, still stands at the stage where further financial deepening promotes higher growth (this point will be explained in later section).

Another angle on financial deepening issues is the composition of financial markets: banking, stock and bond markets. It has often been pointed out that Asian emerging and developing economies have depended highly on banking rather than stock and bond markets in their financial markets. Eichengreen and Luengnaruemitchai (2004), for instance, argued that Asian undeveloped bond markets and dependence on bank finance have been topics of concern since the Asian 1997-98 crisis, and their estimation found that the Asian structural characteristics and macroeconomic and financial policies account for differences in bond market development between Asia and the rest of the world. Mongolian economy is not an exception in that it has relied on banking and has underdeveloped bond and stock markets. The annual report of Central Bank of Mongolia in $2017^{4}$ states that regarding the structure of the whole financial system, over 95 percent of the financial system assets of Mongolian economy is held by the banking sector alone, and the financial market is in the early stage of development.

There are some studies for investigating the factors to prevent the capital market from developing in Mongolian 
economy. Danaasuren (2015), for instance, pointed out the institutional causes for the immature capital market in Mongolia, such as high concentration of listed companies, no institutional investors like pension funds and a lack of highly-skilled specialists and of financial knowledge among the public and companies. Taguchi and Enkhbaatar (2019) analyzed the impediment factors to prevent capital market development from the viewpoint of the biases in macroeconomic policies, and argued that the cumulative public debt and too high policy rate have stagnated the stock prices in Mongolia. There are, however, no explicit studies to examine Mongolian "bond" market with the factors to explain its underdevelopment.

This paper aims to address the issue on bond market development: first, to investigate the determinants of bond market development with a focus on Asian economies based on previous studies' methodologies, and second, to identify the impediment factors to prevent its development in Mongolian economy. The reason why this study targets Asian economies is that there appears to be common characteristics in Asian financial markets such as their high dependence on banking sectors as Eichengreen and Luengnaruemitchai (2004) argued; and that the purpose of this study is to explore the Mongolia-specific factors for her underdeveloped bond market out of its Asian common factors.

The rest of the paper is structured as follows. Section 2 identifies Mongolian position in financial development including bond market development. Section 3 reviews the literature related to the issue on bond market development. Section 4 conducts the empirical analysis to investigate the determinants of bond market development in Asian economies and to extract Mongolia-specific factors. Section 4 summarizes and concludes.

\section{Financial Development in Mongolia}

This section first identifies Mongolian position in financial development by the comprehensive index that has been newly developed in International Monetary Fund (IMF) works, and then confirms the degree of Mongolian financial deepening in individual financial markets: banking, stock and bond markets, with a focus on Asian economies.

Sahay et al. (2015) and Svirydzenka (2016) in the IMF works came up with a new index for financial development by taking into account its complex multidimensional nature: nine indices to represent financial institutions and financial markets in terms of their depth (size and liquidity of markets), access (ability of individuals to access financial services) and efficiency (ability of institutions to provide financial services at low cost and with sustainable revenues, and the level of activity of capital markets). ${ }^{5}$ Mongolian positon in financial development could also be confirmed by this newly-developed index. Figure 1 shows that Mongolia (0.401 of the financial development index at 3,694 US dollars of GDP per capita) stands slightly above on the average line of the index along with GDP per capita in 2016 among Asian economies. ${ }^{6}$

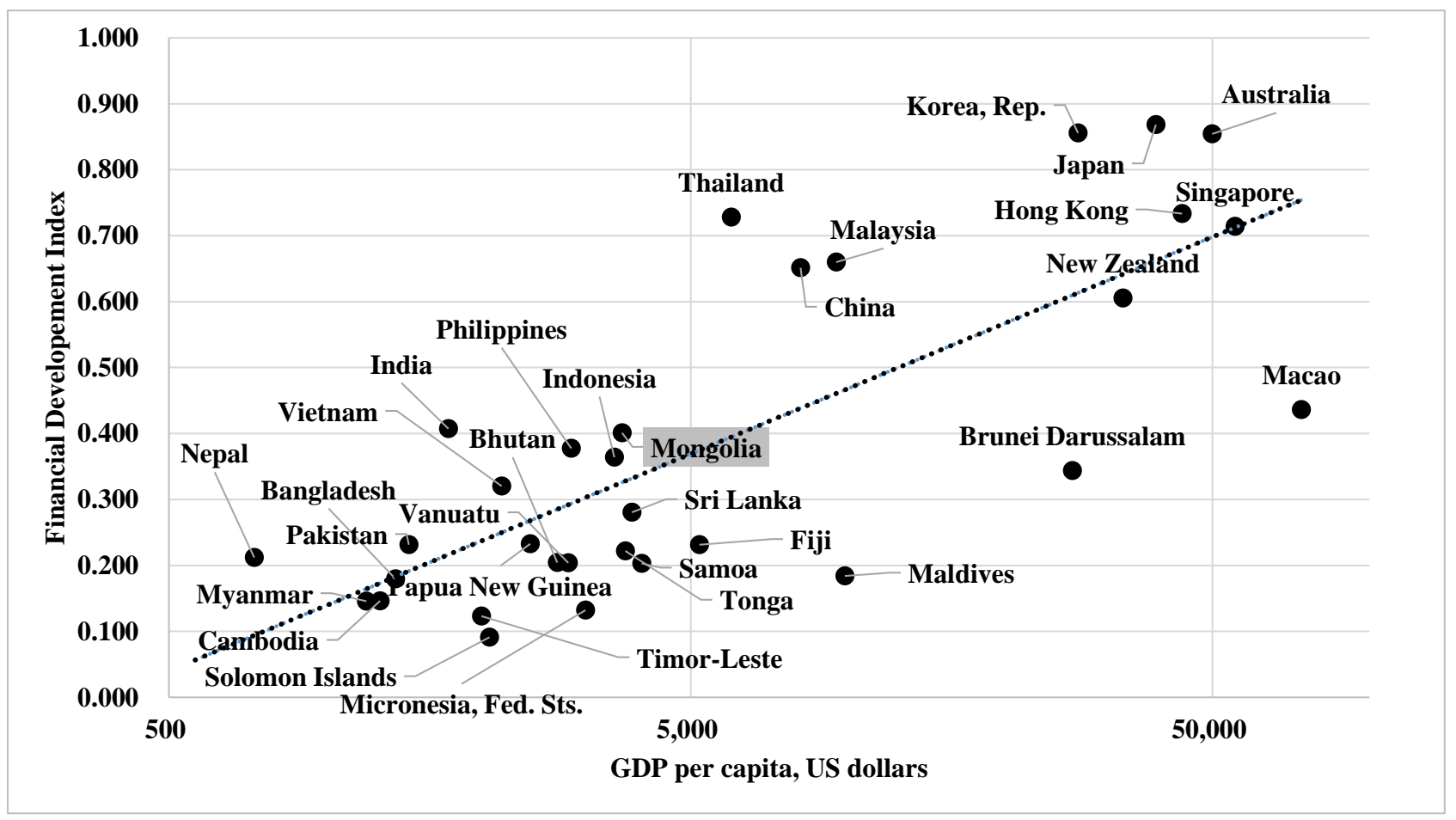

Figure 1. Financial Development and GDP per capita in 2016 in Asian Economies

Source: Author' description based on the Financial Development Index Database of IMF: 
https://data.imf.org/?sk=F8032E80-B36C-43B1-AC26-493C5B1CD33B

The effect of financial development on economic growth was examined by Sahay et al. (2015), using this IMF new index with a sample of 128 countries over 1980-2013. They found that financial development increases growth, but the effect weakens at higher level of financial development, and eventually negative, which is bell-shaped relationship with the turning point being between 0.45 and 0.7 (with 95 percent likelihood) of the financial development index in the range of 4 to 5.5 percentage points of economic growth (see Figure 2). They speculated the following reasons for the bell-shaped relationship: a high frequency of booms and busts, a diversion of human capital from productive sectors, and a high incidence of moral hazard or rent extraction, under too much finance. As Figure 2 indicates, the degree of financial development in Mongolia, 0.401, is still below the range of the turning point between 0.45 and 0.7 , as in cases of other emerging market economies. Mongolian economy is, therefore, in a favorable position where further financial development and deepening promote higher growth, namely, in a growth-enhancing position of financial development.

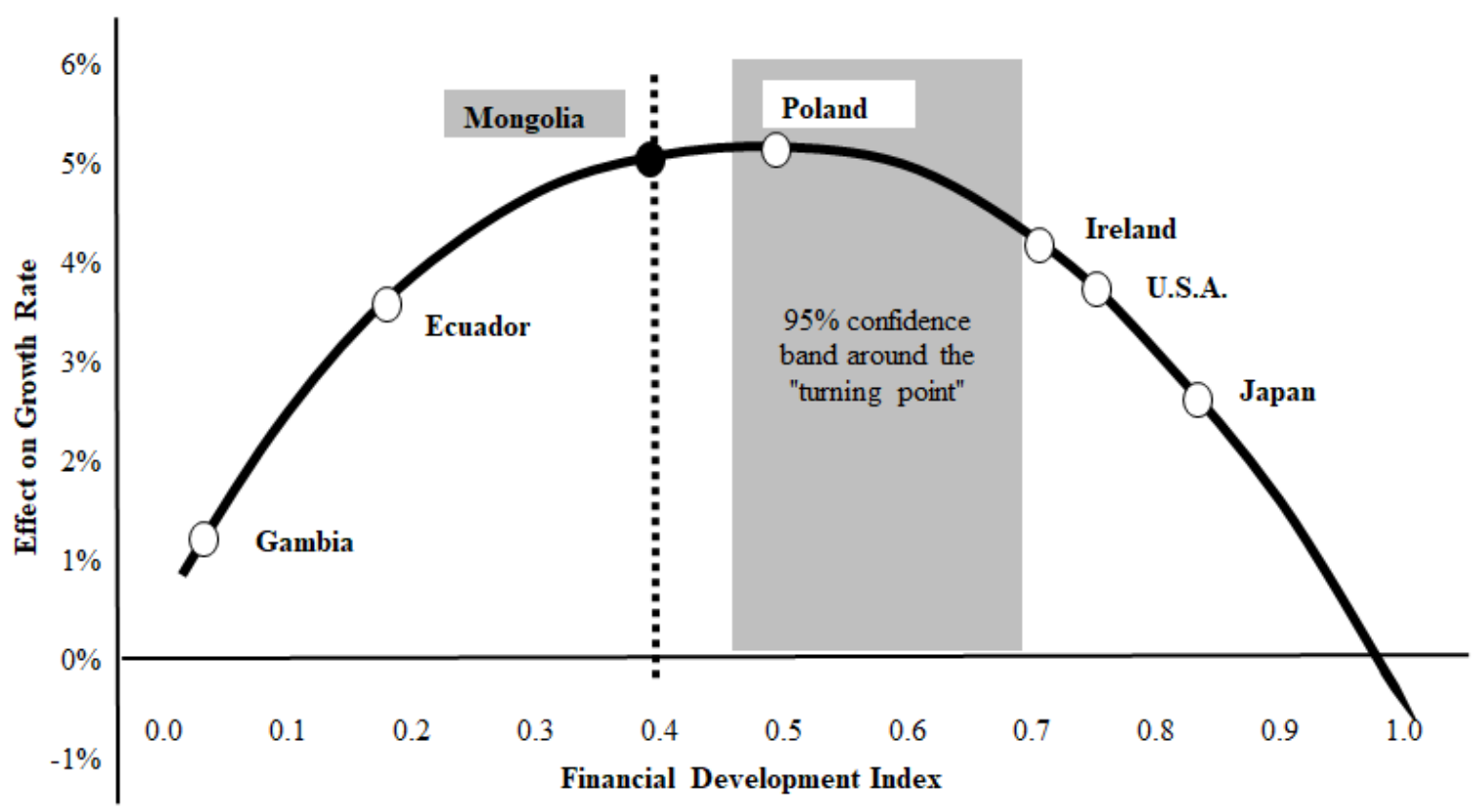

Figure 2. Financial Development Effect on Growth

Source: Author' description based on Sahay et al. (2015)

This section next decomposes the financial deepening in Mongolia into that of individual financial markets: banking, stock and bond markets. Table 1 compares the degree of deepening in Mongolia with those in selected Asian middle-income economies in individual market sizes relative to GDP. It shows that: in the market of public and private debt securities and of private credit by bank, Mongolia occupies middle positions in the range of fourth to sixth ranks among ten Asian economies; and in the stock market, Mongolia ranks at the bottom among them. Considering the characteristic of Asian financial markets with high dependence on banking sector, Mongolia appears to follow the Asian style in her financial deepening. 
Table 1. Financial Deepening in Asian Countries in 2016

\begin{tabular}{|c|c|c|c|}
\hline \multicolumn{4}{|c|}{ Outstanding Debt Securities } \\
\hline \multicolumn{2}{|c|}{ Public Debt } & \multicolumn{2}{|c|}{ Private Debt } \\
\hline Countries & Percentage of GDP & Countries & Percentage of GDP \\
\hline Malaysia & 48.41 & Malaysia & 63.96 \\
\hline Pakistan & 38.38 & China & 58.00 \\
\hline Philippines & 35.01 & Thailand & 52.29 \\
\hline India & 33.42 & Mongolia & 19.40 \\
\hline China & 28.90 & Indonesia & 8.02 \\
\hline Mongolia & 28.28 & Philippines & 6.55 \\
\hline Thailand & 27.90 & Sri Lanka & 2.70 \\
\hline Indonesia & 20.21 & Pakistan & 0.36 \\
\hline Sri Lanka & 10.08 & Vietnam & 0.20 \\
\hline Vietnam & 1.07 & India & - \\
\hline \multicolumn{2}{|c|}{ Private Credit by Banks } & \multicolumn{2}{|c|}{ Stock Market Capitalization } \\
\hline Countries & Percentage of GDP & Countries & Percentage of GDP \\
\hline China & 149.06 & Malaysia & 120.76 \\
\hline Malaysia & 120.07 & Thailand & 93.75 \\
\hline Vietnam & 113.94 & Philippines & 76.59 \\
\hline Thailand & 112.81 & India & 67.46 \\
\hline Mongolia & 52.94 & China & 67.28 \\
\hline India & 48.76 & Indonesia & 41.79 \\
\hline Philippines & 41.41 & Vietnam & 28.60 \\
\hline Sri Lanka & 36.73 & Pakistan & 28.05 \\
\hline Indonesia & 31.88 & Sri Lanka & 22.95 \\
\hline Pakistan & 15.47 & Mongolia & 6.16 \\
\hline
\end{tabular}

Source: Global Financial Development Database (July 2018 Version) by the World Bank: https://www.worldbank.org/en/publication/gfdr/data/global-financial-development-database. The stock market capitalization to GDP is based on the statistical database of the Bank of Mongolia: https://www.mongolbank.mn/eng/dbliststatistic.aspx.

To sum up, the financial development of Mongolia stands slightly above that of Asian average in total, but is still in a growth-enhancing position. Looking at the composition of financial deepening, Mongolia appears to follow the Asian style with high dependence on banking sector.

\section{Literature Review and Contribution}

This section reviews the literature related to the issue on bond market development, in particular, the determinants of its development.

The seminal work in this field in the first place is Eichengreen and Luengnaruemitchai (2004). They examined the determinants of bond market development from comprehensive perspectives such as structural, financial, developmental and macroeconomic factors with a sample of 41 developing and developed economies over the period 1990-2001. The purpose of their study was to identify the factors to prevent Asian bond markets, based on their ideas that Asian financial markets have heavily depended on banking sector, and that they need well-diversified financial systems in terms of deep and liquid bond markets to reduce financial fragility and enhance the efficiency of capital allocation. Their estimation found that the major determinants of bond market development are economic size, trade openness, geographical endowments, corruption, banking concentration, level of interest rate, exchange rate variability, capital control and fiscal balance; and that once these factors are controlled there is no residual "Asian effect".

The seminal work above has been extended by the following subsequent studies. Burger and Warnock (2006), analyzing the development of 49 local bond markets, found that the countries with stable inflation rates and strong creditor rights have more developed local bond markets and rely less on foreign-currency-denominated bonds. Claessens, et al. (2007), using panel data for developed and emerging economies, found that institutional and macroeconomic factors are related to the depth and currency composition of government bond markets. Eichengreen et al. (2008), focusing on Latin American corporate bond markets, showed that a limited number of observable policy variables and country characteristics explain eighty percent of the difference in private bond market capitalization between Latin America and 
the advanced economies. Bae (2012), examining government and corporate bond markets with a sample of 43 countries during 1990-2009, found that mature and well-developed banking sector is critically important to the further development of bond market, particularly to the corporate bond market and provided policy suggestions to further develop bond markets in China. Smaoui et al. (2017), sampling 22 emerging and developing countries over the period 1990-2013, revealed that a combination of structural, financial and institutional factors exerts a significant effect on bond market development.

There are also some studies on bond market development with a regional focus. Adelegan and Radzewicz-Bak (2009), focusing on 23 sub-Saharan African (SSA) countries between 1990 and 2008, showed that a confluence of factors matters for the SSA bond market development, such as structure of the economy, investment profile, law and order, size of the banking sector, the level of economic development and various macroeconomic factors. Mu et al. (2013), sampling 36 SSA countries over the period from 1980 to 2010, found common determinants of developing government and corporate bond markets such as better institution, and volatility and lower spreads of interest rate.

Regarding the determinants of bond market development, although the emphases differ among the previous studies above, the literature has explored common determinants from structural, financial, developmental and macroeconomic factors under the framework proposed by Eichengreen and Luengnaruemitchai (2004). This paper contributes to the literature above by enriching evidence of the determinants of bond market development with a focus on Asian economies with common characteristics such as their high dependence on banking sectors. In particular, while there have been few studies on an individual economy's bond market, the strategic contribution is to identify the Mongolia-specific factors to prevent her bond market development among Asian economies.

\section{Empirics}

This section conducts the empirical analysis to investigate the determinants of bond market development in Asian economies and to extract Mongolia-specific factors. The section starts with clarifying key variables and data, and methodology for an estimation, and then presents the estimation outcomes with their discussions.

\subsection{Key Variables and Data}

Considering the analytical interest above and the data availability below, the estimation constructs the panel data for the period from 1996 to 2016 with the following ten Asian economies: China, India, Indonesia, Malaysia, Mongolia, Pakistan, the Philippines, Sri Lanka, Thailand and Vietnam. The estimation basically adopts the variables common to the previous studies: Smaoui et al. (2017) and Eichengreen and Luengnaruemitchai (2004), but modifies them for the study's concerns. These previous studies explained the development of both public and private bond markets, and adopted around twenty explanatory variables as the bond market determinants under the following hypothesized categories: structural characteristic, developmental stage, governance and regulation of financial sector and macroeconomic policies. This study also targets both public and private bond markets, and selects thirteen variables as their determinants from the same categories as in the previous studies. The selected variables are listed with their measurement, expected sign and data source in Table 2, and their descriptive statistics are presented in Table 3. The details of each variable are described below. 
Table 2. List of Variables for Estimation

\begin{tabular}{|c|c|c|c|}
\hline Variables & Description & Exp. Sign & Source \\
\hline \multicolumn{4}{|c|}{ Dependent Variables: Bond Market Development } \\
\hline PBDP & Outstanding Public Debt Securities [\% of GDP] & & GFDD \\
\hline PVDP & Outstanding Private Debt Securities [\% of GDP] & & GFDD \\
\hline \multicolumn{4}{|c|}{ Explanatory Variables: Structural } \\
\hline GDP & Size of Economy: GDP, PPP-adjusted [USD, log term, lagged] & + & WDI \\
\hline OPEN & Openness: Exports of Goods and Services [\% of GDP, lagged] & $+/-$ & WDI \\
\hline \multicolumn{4}{|c|}{ Explanatory Variables: Developmental } \\
\hline INVP & Investment Profile: ICRG Index [from 0 to 12 ] & + & ICRG \\
\hline LAW & Law and Order: Rule of Law Index [from -2.5 (weak) to 2.5 (strong)] & + & WGI \\
\hline GDPPC & GDP per capita: GDP per capita PPP-adjusted [USD, log term, lagged] & + & WDI \\
\hline \multicolumn{4}{|c|}{ Explanatory Variables: Governance and Regulation of Financial Sector } \\
\hline CORP & Corruption: Control of Corruption Index [from -2.5 (weak) to 2.5 (strong)] & + & WGI \\
\hline GOVE & Bureaucracy Quality: Government Effectiveness Index [ditto] & + & WGI \\
\hline CRED & Bank Credit: Domestic Credit to Private Sector by Banks [\% of GDP] & $+/-$ & WDI \\
\hline CONC & Banking Concentration: Herfindahl Concentration Index [\%] & - & GFDD \\
\hline \multicolumn{4}{|c|}{ Explanatory Variables: Macroeconomic } \\
\hline INTR & Level of Interest Rates: Lending Interest Rate [\%, lagged] & - & WDI \\
\hline INTV & Interest Rate Volatility: Standard Deviation of Lending Interest Rate & - & WDI \\
\hline EXRV & Exchange Rate Volatility: Standard Deviation of Exchange Rate [local currency per USD] & $+/-$ & WDI \\
\hline FISB & Fiscal Balance: General Government Net Lending/Borrowing [\% of GDP, lagged] & - & WEO \\
\hline
\end{tabular}

Notes: The data sources are shown as follows: GFDD: Global Financial Development Database, World Bank; WDI: World Development Indicators, World Bank; ICRG: International Country Risk Guide Database, PRS Group; WGI: Worldwide Governance Indicators, World Bank; WEO: World Economic Outlook Databases, International Monetary Fund. Source: Author's description 
Table 3. Descriptive Statistics

\begin{tabular}{|c|c|c|c|c|c|}
\hline Variables & Obs. & Mean & Std. Dev. & Min. & Max \\
\hline \multicolumn{6}{|c|}{ Dependent Variables: Bond Market Development } \\
\hline PBDP & 189 & 20.30 & 15.68 & 0.25 & 56.97 \\
\hline PVDP & 163 & 18.22 & 22.14 & 0.17 & 79.63 \\
\hline \multicolumn{6}{|c|}{ Explanatory Variables: Structural } \\
\hline GDP & 210 & 26.98 & 1.71 & 22.72 & 30.70 \\
\hline OPEN & 210 & 43.34 & 26.47 & 9.15 & 121.31 \\
\hline \multicolumn{6}{|c|}{ Explanatory Variables: Developmental } \\
\hline INVP & 210 & 7.54 & 1.30 & 2.42 & 10.00 \\
\hline LAW & 180 & -0.23 & 0.40 & -0.97 & 0.59 \\
\hline GDPPC & 210 & 8.67 & 0.64 & 7.35 & 10.23 \\
\hline \multicolumn{6}{|c|}{ Explanatory Variables: Governance and Regulation of Financial Sector } \\
\hline CORP & 180 & -0.44 & 0.33 & -1.22 & 0.45 \\
\hline GOVE & 180 & -0.05 & 0.45 & -0.82 & 1.27 \\
\hline CRED & 210 & 60.84 & 41.74 & 4.74 & 166.50 \\
\hline CONC & 203 & 58.02 & 20.95 & 28.80 & 100.00 \\
\hline \multicolumn{6}{|c|}{ Explanatory Variables: Macroeconomic } \\
\hline INTR & 193 & 11.88 & 7.26 & 4.33 & 48.06 \\
\hline INTV & 193 & 2.81 & 3.02 & 0.04 & 20.78 \\
\hline EXRV & 210 & 15.85 & 14.15 & 0.05 & 74.51 \\
\hline FISB & 208 & -3.51 & 3.46 & -16.98 & 7.59 \\
\hline
\end{tabular}

Source: Author's description

\subsubsection{Bond Market Development}

Regarding the dependent variables, namely, the development indicators of public and private bond markets, their data are retrieved from the Global Financial Development Database (GFDD) of the World Bank. ${ }^{7}$ The public bond market development (PBDP) and the private one (PVDP) are measured by "Outstanding domestic and international public debt securities" and "Outstanding domestic and international private debt securities" as a percentage of GDP, respectively. The debt securities above cover long-term bonds and notes, treasury bills, commercial paper and other short-term notes, and money market instruments placed on international markets.

\subsubsection{Structural Characteristic}

As for the bond market determinants, the first category of "structural characteristic" adopts two variables: a size of economy (GDP) and trade openness (OPEN). Their data come from the World Development Indicator (WDI) of the World Bank. GDP is expressed as purchasing-power-parity (PPP) adjusted one in terms of international US dollars, transformed in logarithm to avoid scaling issue, and lagged by one year to consider its endogeneity in the estimation. The coefficient of GDP is expected to have a positive sign due to a consequence of economies of scale: larger economies would decrease the average lending cost and risks and thus promote a broader access of firms and governments to bond financing. OPEN is measured by exports of goods and services as a percentage of GDP, and lagged by one year to consider its endogeneity. The coefficient of OPEN seems to be ambiguous in its sign, since a higher openness might crowd out bond finance through open capital accounts whereas it might require more of bond finance to cope with enlarged production and consumption. The variables the previous studies used as structural factors, namely, "Asia dummy", "English legal origin" and "distance from equator", are not applied in this study: the Asian dummy is not necessary due to the Asian-focus estimation, and the latter two time-invariant variables are dealt with as an fixed effect in this study's estimation.

\subsubsection{Developmental Stage}

The second category of "developmental stage" contains three variables: investment profile (INVP), law and order 
(LAW), and GDP per capita (GDPPC). The data of INVP are retrieved from the International Country Risk Guide (ICRG) Database of the PRS Group. It indicates the factors affecting the risk to investment (contract viability and expropriation, profits repatriation and payment delays), taking the number ranging from 0 (high risk) to 12 (low risk). The data of LAW are taken from the World Governance Indicators (WGI) of the World Bank. It is measured by the "Rule of Law Index" taking the number ranging from -2.5 (weak) to 2.5 (strong). The data of GDPPC come from the WDI. GDPPC is expressed as PPP-adjusted one in terms of international US dollars, transformed in logarithm to avoid scaling issue, and lagged by one year to cope with its endogeneity. The coefficients of all three variables in this category are expected to have positive signs, since the economies with the larger values of these variables stand at the higher development stages, thereby requiring the large financing through bond markets.

\subsubsection{Governance and Regulation of Financial Sector}

The third category of "governance and regulation of financial sector" comprises four variables: corruption (CORP), bureaucracy quality (GOVE), bank credit (CRED) and banking concentration (CONC). The data of CORP and GOVE are retrieved from the WGI and shown by the "Control of Corruption Index" and the "Government Effectiveness Index", respectively, taking the number ranging from -2.5 (weak) to 2.5 (strong). Their coefficients are expected to have positive signs. The data of CRED are taken from the WDI and measured by the "Domestic Credit to Private Sector" as a share of GDP. The sign of its coefficient is ambiguous, since banking system and bond markets could be either complements or substitutes. The data of COND come from the GFDD and represented by the "Herfindahl Concentration Index" as a percentage. Its coefficient is expected to have a negative sign, since the banks with market power might attempt to stifle the bond market development by setting loan and deposit rates strategically.

\subsubsection{Macroeconomic Policies}

The last category of "macroeconomic policies" includes four variables: level of interest rate (INTR), interest rate volatility (INTV), exchange rate volatility (EXRV), and fiscal balance (FISB). The data of INTR, INTV and EXRV are taken from the WDI. INTR is represented by the "Lending Interest Rate" as a percentage, and lagged by one year to cope with its endogeneity. The coefficient of INTR is expected to have a negative sign since governments and corporations would be less willing to borrow through bond issuance under high interest rates. INTV is shown by the standard deviation of the "Lending Interest Rate", and its coefficient is also expected to have a negative sign since volatile interest rates would discourage investors from investing in bond markets due to the high risk. EXRV is indicated by the standard deviation of the exchange rate in terms of local currency value per US dollar. The sign of its coefficient is ambiguous, since fixed exchange rates pose low risk to foreign investors, while leading them to underestimate the risk of lending so that the development of domestic intermediation could be hindered. The data of FISB is retrieved from the World Economic Outlook Database of the International Monetary Fund. It is shown by the "General Government Net Lending/ Borrowing" as a share of GDP, and lagged by one year to cope with its endogeneity. The sign of its coefficient is expected to be negative since the larger fiscal deficits are usually associated with the larger government bond markets. The variable the previous studies adopted as macroeconomic policies, namely, "Capital Control", is not applied in this study, since the variable is treated with by an fixed effect in this study's estimation as a time-invariant variable.

\subsection{Methodology}

This section then turns to describing the estimation model and method to investigate the determinants of bond market development in a panel setting. The panel estimation model could be specified as follows.

$$
\begin{aligned}
{\left[\mathrm{PBDP}_{i t}, \mathrm{PVDP}_{i t}\right]=\alpha_{0}+\alpha_{1} \mathrm{GDP}_{i t}+\alpha_{2} \mathrm{OPEN}_{i t}+\alpha_{3} \mathrm{INVP}_{i t}+\alpha_{4} \mathrm{LAW}_{i t}+\alpha_{5} \mathrm{GDPPC}_{i t}+\alpha_{6} \mathrm{CORP}_{i t}+\alpha_{7} \mathrm{GOVE}_{i t}+\alpha_{8} \mathrm{CRED}_{i t} } & \\
& +\alpha_{9} \mathrm{CONC}_{i t}+\alpha_{10} \mathrm{INTR}_{i t}+\alpha_{11} \mathrm{INTV}_{i t}+\alpha_{12} \mathrm{EXRV}_{i t}+\alpha_{13} \mathrm{FISB}_{i t}+\mu_{i}+\varepsilon_{i t}
\end{aligned}
$$

where $i$ and $t$ are the country and the time period; $\alpha_{0} \ldots \alpha_{13}$ are a constant term and a parameter of each determinant variable; $\mu_{i}$ is an unobserved country-specific effect; and $\varepsilon_{i t}$ is an error term, respectively.

There would be a threat of multicollinearity among the explanatory variables. Table 4 indicates the variance inflation factor (VIF), a method of measuring the level of collinearity between the regressors in the estimation. In case that the full-set of variables are included in the estimation in the column (a) in both PBDP and PVDP estimation, eight of thirteen variables are beyond the criteria of collinearity, namely, ten points in VIF. Then the separate estimations by each category of the determinant variables in the columns from (b) to (e) make the VIF fall down below its criteria of ten points except for the category of developmental stage. The study thus conducts the estimations by the categories of the determinant variables as well as by the full-set of variables. 
Table 4. Variance Inflation Factor

\begin{tabular}{|c|c|c|c|c|c|}
\hline PBDP & (a) & (b) & (c) & (d) & (e) \\
\hline \multicolumn{6}{|c|}{ Structural } \\
\hline GDP & 341.68 & 3.20 & & & \\
\hline OPEN & 11.36 & 3.20 & & & \\
\hline \multicolumn{6}{|c|}{ Developmental } \\
\hline INVP & 69.01 & & 39.36 & & \\
\hline LAW & 6.99 & & 1.34 & & \\
\hline GDPPC & 347.79 & & 40.83 & & \\
\hline \multicolumn{6}{|c|}{ Governance and Regulation of Financial Sector } \\
\hline CORP & 19.41 & & & 5.92 & \\
\hline GOVE & 7.49 & & & 3.61 & \\
\hline CRED & 13.32 & & & 4.27 & \\
\hline CONC & 11.44 & & & 4.85 & \\
\hline \multicolumn{6}{|c|}{ Macroeconomic } \\
\hline INTR & 19.48 & & & & 5.48 \\
\hline INTV & 4.21 & & & & 3.32 \\
\hline EXRV & 2.85 & & & & 2.37 \\
\hline FISB & 3.24 & & & & 2.20 \\
\hline PVDP & (a) & (b) & (c) & (d) & (e) \\
\hline \multicolumn{6}{|c|}{ Structural } \\
\hline GDP & 399.56 & 3.31 & & & \\
\hline OPEN & 13.58 & 3.31 & & & \\
\hline \multicolumn{6}{|c|}{ Developmental } \\
\hline INVP & 75.57 & & 38.87 & & \\
\hline LAW & 6.11 & & 1.22 & & \\
\hline GDPPC & 357.34 & & 39.77 & & \\
\hline \multicolumn{6}{|c|}{ Governance and Regulation of Financial Sector } \\
\hline CORP & 17.34 & & & 4.82 & \\
\hline GOVE & 7.48 & & & 3.24 & \\
\hline CRED & 15.96 & & & 4.33 & \\
\hline CONC & 12.83 & & & 4.72 & \\
\hline \multicolumn{6}{|c|}{ Macroeconomic } \\
\hline INTR & 20.29 & & & & 5.30 \\
\hline INTV & 4.34 & & & & 3.48 \\
\hline EXRV & 2.68 & & & & 2.26 \\
\hline FISB & 3.00 & & & & 2.03 \\
\hline
\end{tabular}

Source: Author's estimation

Regarding the estimation methodology, the study applies a fixed-effect model in the panel setting. From the statistical perspective, it is usual that the Hausman-test statistics (see Hausman, 1978) is utilized for the choice between a fixed-effect model and a random-effect one. This study, however, places a premium on the existence of country-specific and time-invariant effects that are supposed to affect bond market development. These effects contain the "English legal origin" and "distance from equator" as picked up in 4.1 and might also include any other unobserved country-specific factors as well. Since these factors are not randomly distributed among the sample economies, the estimations in this study adopts a fixed-effect model.

\subsection{Estimation Outcomes}

Table 5 reports the estimation outcomes on public bond market development (PBDP) and private one (PVDP). The outcomes are summarized as follows. 
Table 5. Estimation Outcomes

[Outstanding Public Debt Securities]

\begin{tabular}{|c|c|c|c|c|c|}
\hline PBDP & (a) & (b) & (c) & (d) & (e) \\
\hline \multicolumn{6}{|l|}{ Structural } \\
\hline \multirow[t]{2}{*}{ GDP } & $28.76 * *$ & $6.63 * * *$ & & & \\
\hline & $(2.04)$ & $(6.86)$ & & & \\
\hline \multirow[t]{2}{*}{ OPEN } & 0.03 & $0.08 *$ & & & \\
\hline & $(0.62)$ & $(1.82)$ & & & \\
\hline \multicolumn{6}{|c|}{ Developmental } \\
\hline \multirow[t]{2}{*}{ INVP } & $-0.80 * * *$ & & -0.49 & & \\
\hline & $(-3.32)$ & & $(-0.97)$ & & \\
\hline \multirow[t]{2}{*}{ LAW } & $-5.62 *$ & & $-7.56 * * *$ & & \\
\hline & $(-1.76)$ & & $(-3.78)$ & & \\
\hline \multirow[t]{2}{*}{ GDPPC } & -26.05 & & $7.67 * * *$ & & \\
\hline & $(-1.61)$ & & $(4.95)$ & & \\
\hline \multicolumn{6}{|c|}{ Governance and Regulation of Financial Sector } \\
\hline \multirow[t]{2}{*}{ CORP } & $-9.35 * *$ & & & $-11.11 * * *$ & \\
\hline & $(-1.99)$ & & & $(-3.60)$ & \\
\hline \multirow[t]{2}{*}{ GOVE } & -3.10 & & & $12.68 * *$ & \\
\hline & $(-0.60)$ & & & $(2.31)$ & \\
\hline \multirow[t]{2}{*}{ CRED } & 0.03 & & & -0.04 & \\
\hline & $(1.25)$ & & & $(-1.03)$ & \\
\hline \multirow[t]{2}{*}{$\mathrm{CONC}$} & 0.04 & & & $-0.07 *$ & \\
\hline & (1.16) & & & $(-1.76)$ & \\
\hline \multicolumn{6}{|c|}{ Macroeconomic } \\
\hline \multirow[t]{2}{*}{ INTR } & -0.16 & & & & $-0.50 * *$ \\
\hline & $(-0.59)$ & & & & $(-2.25)$ \\
\hline \multirow[t]{2}{*}{ INTV } & $-0.16 * * *$ & & & & $-0.80 * *$ \\
\hline & $(-5.25)$ & & & & $(-2.45)$ \\
\hline \multirow[t]{2}{*}{ EXRV } & $0.25 * * *$ & & & & $0.17 *$ \\
\hline & $(5.64)$ & & & & $(1.96)$ \\
\hline \multirow[t]{2}{*}{ FISB } & 0.19 & & & & -0.18 \\
\hline & $(0.733)$ & & & & $(-0.45)$ \\
\hline \multirow[t]{2}{*}{ Const. } & $-543.58 * *$ & $-164.25 * * *$ & $-44.45^{* * *}$ & $22.69 * * *$ & $24.00 * * *$ \\
\hline & $(-2.18)$ & $(-6.28)$ & $(-3.24)$ & $(6.45)$ & $(8.67)$ \\
\hline Adjusted $\mathrm{R}^{2}$ & 0.89 & 0.82 & 0.84 & 0.81 & 0.81 \\
\hline Observation & 147 & 182 & 157 & 164 & 167 \\
\hline
\end{tabular}


[Outstanding Private Debt Securities]

\begin{tabular}{|c|c|c|c|c|c|}
\hline PVDP & (a) & (b) & (c) & (d) & (e) \\
\hline \multicolumn{6}{|l|}{ Structural } \\
\hline GDP & $\begin{array}{c}-46.48 * * \\
(-2.55)\end{array}$ & $\begin{array}{c}14.89 * * * \\
(19.99)\end{array}$ & & & \\
\hline OPEN & $\begin{array}{c}0.07 \\
(1.31)\end{array}$ & $\begin{array}{c}0.35 * * * \\
(19.99)\end{array}$ & & & \\
\hline \multicolumn{6}{|c|}{ Developmental } \\
\hline INVP & $\begin{array}{c}-0.39 \\
(-0.78)\end{array}$ & & $\begin{array}{c}-0.948 * * \\
(-2.05)\end{array}$ & & \\
\hline LAW & $\begin{array}{c}-2.57 \\
(-0.66)\end{array}$ & & $\begin{array}{c}-12.81 * * * \\
(-5.77)\end{array}$ & & \\
\hline GDPPC & $\begin{array}{c}-76.09 * * * \\
(3.70) \\
\end{array}$ & & $\begin{array}{c}15.57^{* * *} \\
(11.55) \\
\end{array}$ & & \\
\hline \multicolumn{6}{|c|}{ Governance and Regulation of Financial Sector } \\
\hline CORP & $\begin{array}{c}-2.96 \\
(-0.78)\end{array}$ & & & $\begin{array}{c}-20.30 * * * \\
(-4.62)\end{array}$ & \\
\hline GOVE & $\begin{array}{l}-5.00 \\
(-0.92)\end{array}$ & & & $\begin{array}{c}24.49 * * * \\
(5.75)\end{array}$ & \\
\hline CRED & $\begin{array}{c}-0.18^{* *} \\
(-2.07)\end{array}$ & & & $\begin{array}{c}0.06 \\
(0.88)\end{array}$ & \\
\hline $\mathrm{CONC}$ & $\begin{array}{c}0.09 \\
(1.48) \\
\end{array}$ & & & $\begin{array}{c}0.03 \\
(0.62) \\
\end{array}$ & \\
\hline \multicolumn{6}{|c|}{ Macroeconomic } \\
\hline INTR & $\begin{array}{c}0.14 \\
(0.63)\end{array}$ & & & & $\begin{array}{c}-0.81 * * * \\
(-3.29)\end{array}$ \\
\hline INTV & $\begin{array}{l}0.18 \\
(0.38)\end{array}$ & & & & $\begin{array}{c}0.05 \\
(0.15)\end{array}$ \\
\hline EXRV & $\begin{array}{l}-0.07 * \\
(-1.70)\end{array}$ & & & & $\begin{array}{c}0.01 \\
(0.32)\end{array}$ \\
\hline FISB & $\begin{array}{c}-0.03 \\
(-0.06)\end{array}$ & & & & $\begin{array}{c}0.50 \\
(0.86)\end{array}$ \\
\hline Const. & $\begin{array}{c}627.52 * \\
(1.94)\end{array}$ & $\begin{array}{c}-404.65^{* * *} \\
(-20.23)\end{array}$ & $\begin{array}{c}-113.17^{* * *} \\
(-11.95)\end{array}$ & $\begin{array}{c}3.21 \\
(0.51)\end{array}$ & $\begin{array}{c}29.29 * * * \\
(14.17)\end{array}$ \\
\hline Adjusted $R^{2}$ & 0.94 & 0.90 & 0.91 & 0.86 & 0.83 \\
\hline Observation & 127 & 156 & 134 & 141 & 145 \\
\hline
\end{tabular}

Note: $* * *, * * *$ denote rejection of null hypothesis at the $99 \%, 95 \%$ and $90 \%$ level of significance, respectively. The figure in ( ) are t-value. Source: Author's estimation

Regarding the category of structural characteristic, a size of economy (GDP) and trade openness (OPEN) are identified to have positive effects as expected in both public (PBDP) and private (PVDP) bond market development when they are treated as an independent category in the column (b). It should be noted that in the column (a) including all the determinant variables the effect of GDP is significantly negative in PVDP and those of OPEN are insignificant in both PBDP and PVDP against expectations. These result in the column (a) could be attributed to the regressors' multicollinearity problem as shown in the VIF in Table 4 (thus the column (a) will be ignored hereafter). On the category of developmental stage, only the determinant of GDP per capita (GDPPC) has an expectedly positive impact on both bond market development, while the variables of investment profile (INVP) and law and order (LAW) have negative impacts against expectations. It is considered to be due to the regressors' multicollinearity problem even within the separated category of development stage, where the VIFs of NVP GDPPC are far beyond ten point in Table 4.

The categories of "governance and regulation of financial sector" and "macroeconomic policies" contain the bond market determinants that are manageable for policy makers. The estimation results in the category of governance and regulation of financial sector show that: corruption (CORP) has unexpectedly negative effects on both markets; 
bureaucracy quality (GOVE) has expectedly positive effects on both markets; bank credit (CRED) has no significant impacts on both markets; and banking concentration (CONC) has an expectedly negative effect only on public bond market. The estimation outcomes in the category of macroeconomic policies reveal that: level of interest rate (INTR) has expectedly negative effects on both markets; interest rate volatility (INTV) had an expectedly negative effect only on public bond market: exchange rate volatility (EXRV) had an positive effect only on public bond market; and the effects of fiscal balance (FISB) are insignificant in both markets.

It is true that the previous studies such as Smaoui et al. (2017) and Eichengreen and Luengnaruemitchai (2004) could not necessarily obtain expected results for all of hypothesized determinants for bond market development, and major determinants differed according to their estimations. The emphasis of this study is that two manageable variables, namely, bureaucracy quality (GOVE) and level of interest rate (INTR), are major determinants for both public and private bond market development.

\subsection{Mongolia-specific Factors}

This subsection turns to extract Mongolia-specific factors for her underdeveloped bond market out of its Asian common factors. Mongolia currently stands at a middle position in the degree of bond market development among Asian economies, as described in Table 1 in Section 2. It would, therefore, be significant to identify the Mongolian manageable determinants that are behind the average of Asian economies and thus could be improved to facilitate bond market development.

Table 6 reveals a factor analysis for Mongolian (public and private) bond market development with a focus on the manageable determinants in the categories of "governance and regulation of financial sector" and "macroeconomic policies" for the period of 1996-2016. It first calculates the difference in the value of each determinant between Mongolia and Asian average in the column (c), and then works out its contribution to PBDP and PVDP in the column (e) by multiplying the difference with the estimated coefficient in Table 5 . In this analysis, the major negative contributors are bureaucracy quality (GOVE) and level of interest rate (INTR) in both public and private bond markets (PBDP and PVDP). There are large gaps between Mongolian level and Asian average level in the determinants of GOVE and INTR, which have powerful coefficients as impacts on both bond market development: Mongolian level of GOVE (-0.42) is much lower than that of Asian average (-0.01), and Mongolian rate of INTR (27.29) is extremely higher than that of Asian average (10.28). These gaps then contribute to pushing down the bond-GDP ratios by around 14 percent points in the public bond and by around 24 percent points in the private bond. It means that there could be still much room for Mongolian bond market to be further developed if Mongolia enhanced her bureaucracy quality and reduced the level of interest rate. 
Table 6. Factor Analysis of Bond Market Development in Mongolia for 1996-2016

\begin{tabular}{|c|c|c|c|c|c|}
\hline PBDP & \multicolumn{2}{|c|}{ Value of MongolizValue of Asian Average } & $\begin{array}{l}\text { differences } \\
\qquad \mathrm{c}=\mathrm{a}-\mathrm{b}\end{array}$ & $\begin{array}{c}\text { coefficients } \\
\text { d }\end{array}$ & $\begin{array}{l}\text { factors } \\
\mathrm{e}=\mathrm{c} * \mathrm{~d}\end{array}$ \\
\hline \multicolumn{6}{|c|}{ Governance and Regulation of Financial Sector } \\
\hline CORP & -0.44 & -0.45 & 0.01 & opposite sign & \\
\hline GOVE & -0.42 & -0.01 & -0.41 & $12.68 * *$ & -5.20 \\
\hline CRED & 30.05 & 64.27 & -34.22 & -0.04 & 1.37 \\
\hline $\mathrm{CONC}$ & 93.15 & 54.97 & 38.18 & $-0.07 *$ & -2.67 \\
\hline \multicolumn{6}{|c|}{ Macroeconomics } \\
\hline INTR & 27.29 & 10.28 & 17.01 & $-0.50 * *$ & -8.51 \\
\hline INTV & 8.16 & 2.23 & 5.93 & $-0.80 * *$ & -4.74 \\
\hline EXRV & 21.28 & 15.25 & 6.03 & $0.17^{*}$ & 1.03 \\
\hline FISB & -4.99 & -3.35 & -1.64 & -0.18 & 0.30 \\
\hline PVDP & Value of Mon & f Asian Average & differences & coefficients & factors \\
\hline & $\mathrm{a}$ & $\mathrm{b}$ & $\mathrm{c}=\mathrm{a}-\mathrm{b}$ & $\mathrm{d}$ & $\mathrm{e}=\mathrm{c}^{*} \mathrm{~d}$ \\
\hline \multicolumn{6}{|c|}{ Governance and Regulation of Financial Sector } \\
\hline CORP & -0.44 & -0.45 & 0.01 & opposite sign & \\
\hline GOVE & -0.42 & -0.01 & -0.41 & $24.49 * * *$ & -10.04 \\
\hline CRED & 30.05 & 64.27 & -34.22 & 0.06 & -2.05 \\
\hline $\mathrm{CONC}$ & 93.15 & 54.97 & 38.18 & opposite sign & \\
\hline \multicolumn{6}{|c|}{ Macroeconomics } \\
\hline INTR & 27.29 & 10.28 & 17.01 & $-0.81 * * *$ & -13.78 \\
\hline INTV & 8.16 & 2.23 & 5.93 & opposite sign & \\
\hline EXRV & 21.28 & 15.25 & 6.03 & 0.01 & 0.06 \\
\hline FISB & -4.99 & -3.35 & -1.64 & opposite sign & \\
\hline
\end{tabular}

Note: $* * *, * * *$ denote rejection of null hypothesis at the $99 \%, 95 \%$ and $90 \%$ level of significance, respectively. Source: Author's estimation

Regarding the high interest rate in Mongolian financial market in recent times, it seems to be caused by the policy stance of the Mongolian monetary authority. Taguchi and Khishigjargal (2018) and Taguchi and Enkhbaatar (2019) argued that the high policy rate in Mongolia would reflect the fact that the Mongolian monetary authority has been suffering from so-called "fear of floating" proposed by Calvo and Reinhart (2002): the policy rate has been too sensitive to the balance-of-payment position and the fluctuation of exchange rate. In order to normalize the level of policy rate, they suggested that: Mongolian economy should have more foreign reserves to cope with foreign capital mobility; and from the long-term perspective, the economy should diversify manufacturing industries to maximize the advantage of currency depreciation in export side and to minimize its disadvantage in import side.

\section{Concluding Remarks}

This paper aims to address the issue on bond market development by investigating the determinants of bond market development with a focus on Asian economies, and also by identifying the impediment factors to prevent its development in Mongolian economy. The reason why this study targets Asian economies is that there appears to be common characteristics in Asian financial markets such as their high dependence on banking sectors as Eichengreen and Luengnaruemitchai (2004) argued; and that the purpose of this study is to explore the Mongolia-specific factors for 
her underdeveloped bond market out of its Asian common factors. The estimation result shows that the two manageable variables, namely, bureaucracy quality (GOVE) and level of interest rate (INTR), are major determinants for both public and private bond market development in Asian economies, and also that these determinants are major factors to prevent the Mongolian (public and private) bond market from developing. It implies that there could be still much room for Mongolian bond market to be further developed if Mongolia enhanced her bureaucracy quality and reduced the level of interest rate.

\section{References}

Adelegan, O. J., \& Radzewicz-Bak, B. (2009). What Determines Bond Market Development in Sub-Saharan Africa?. Washington, DC: International Monetary Fund. https://doi.org/10.5089/9781451873603.001

Bae, K. H. (2012). Determinants of local currency bonds and foreign holdings: Implications for bond market development in the People's Republic of China. ADB Working Paper Series on Regional Economic Integration, No 97.

Burger, J., \& Warnock, F. (2006). Local currency bond markets. National Bureau of Economic Research (NBER) Working Papers, No. w12552. https://doi.org/10.3386/w12552

Calvo, G., \& Reinhart, C. (2002). Fear of floating. The Quarterly Journal of Economics, 117(2), 379-408. https://doi.org/10.1162/003355302753650274

Claessens, S., Klingebiel, D., \& Schmukler, S.L. (2007). Government bonds in domestic and foreign currency: the role of institutional and macroeconomic factors. Review of International Economics, 15(2), $370-413$. https://doi.org/10.1111/j.1467-9396.2007.00682.x

Danaasuren, V. (2015). Capital Market Development in Mongolia. The Northeast Asian Economic Review, 3(2), $17-27$.

Eichengreen, B., \& Luengnaruemitchai, P. (2004). Why doesn't Asia have bigger bond markets?. National Bureau of Economic Research (NBER) Working Papers, No. w10576. https://doi.org/10.3386/w10576

Eichengreen, B., Panizza, U., \& Borensztein, E. (2008). Prospects for Latin American bond markets: A cross-country view. In E. Borensztein, K. Cowan, B. Eichengreen \& U. Panizza (Eds.), Bond markets in Latin America: On the verge of a big bang? (pp. 247-290). Cambridge: MIT Press. https://doi.org/10.7551/mitpress/9780262026321.003.0009

Hausman, J. A. (1978). Specification Tests in Econometrics. Econometrica, 46(6), 1251-1272. https://doi.org/10.2307/1913827

Levine, R. (2005). Finance and Growth: Theory and Evidence. In P. Aghion \& S. Durlauf (Eds.), Handbook of Economic Growth (pp. 865-934). New York: Elsevier. https://doi.org/10.1016/S1574-0684(05)01012-9

McKinnon, R. (1973). Money and Capital in Economic Development. Washington, DC: The Brookings Institution.

Mu, Y., Phelps, P., \& Stotsky, J. (2013). Bond markets in Africa. International Monetary Fund Working Papers, No. 13(12). https://doi.org/10.5089/9781475527148.001

Sahay, R., Čihák, M., N’Diaye, P., Barajas, A., Bi, R., Ayala, D., ... Yousefi, S. R. (2015). Rethinking Financial Deepening: Stability and Growth in Emerging Markets. IMF Staff Discussion Note SDN/15/08. https://doi.org/10.5089/9781498312615.006

Shaw, E. (1973). Financial Deepening in Economic Development. New York: Oxford University Press.

Smaoui, H., Grandes, M., \& Akindele, A. (2017). The Determinants of Bond Market Development: Further Evidence from Emerging and Developed Countries. Emerging Markets Review, 32, 148-167. https://doi.org/10.1016/j.ememar.2017.06.003

Svirydzenka, K. (2016). Introducing a New Broad-based Index of Financial Development. IMF Working Paper WP/16/5. https://doi.org/10.5089/9781513583709.001

Taguchi, H., \& Enkhbaatar, N. (2019). Stock Market and Macroeconomic Policies in Mongolia. Bulletin of Applied Economics, 6(1), 21-39.

Taguchi, H., \& Khishigjargal, E. (2018). Monetary Policy Rule under Inflation Targeting in Mongolia. East Asian Economic Review, 22(4), 531-555. https://doi.org/10.11644/KIEP.EAER.2018.22.4.353 


\section{Notes}

Note 1 . The real economic growth is shown by the growth rate of real GDP, which is retrieved by "US Dollars at constant prices (2010) in millions" from UNCTAD STAT: http://unctadstat.unctad.org/EN/.

Note 2. See the website: https://datahelpdesk.worldbank.org/knowledgebase/articles/906519.

Note 3. See the Global Financial Development Database (July 2018 Version) by the World Bank: https://www.worldbank.org/en/publication/gfdr/data/global-financial-development-database.

Note 4. See the website: https://www.mongolbank.mn/eng/listpublications.aspx.

Note 5. The database of "Financial Development Index" of IMF are presented in the website: https://data.imf.org/?sk=F8032E80-B36C-43B1-AC26-493C5B1CD33B.

Note 6. The Asia in Figure 1 covers "East Asia \& Pacific" and "South Asia" in the World Bank classification.

Note 7. See the website: https://datacatalog.worldbank.org/dataset/global-financial-development.

\section{Copyrights}

Copyright for this article is retained by the author(s), with first publication rights granted to the journal.

This is an open-access article distributed under the terms and conditions of the Creative Commons Attribution license which permits unrestricted use, distribution, and reproduction in any medium, provided the original work is properly cited. 